\title{
Fonksiyonel Bir Besin: Kinoa
}

\section{A Functional Food: Quinoa}

\section{Hatice Özçalışkan İlkay¹, Aslı Akyol Mutlu²}

Geliş tarihi/Received: 04.05.2020 • Kabul tarihi/Accepted: 19.10.2020

\section{ÖZET}

Kinoa, Güney Amerika’nın And Dağları bölgesindeki uygarlıkların tarımından köken alan, günümüzde ise fonksiyonel besin özelliği ile yeniden gündemde olan çift çenekli bir bitkidir. Amaranthaceae familyasına ait olan kinoanın, sistematik ve morfolojik yapısı geleneksel tahıllardan farklı olsa da kinoa tam tahıllar grubuna dahil edilmiştir. Kinoa, kazein proteinine eşdeğer kalitede protein, yağlı tohumların yağ asitleri profiline benzer örüntüde doymamıs yağ asitleri, posa, çeşitli vitaminler ve biyoyararlılı̆̆ yüksek mineraller içermektedir. Ayrıca aralarında saponinler, fitosteroller, fitoekdisteroidler ve biyoaktif peptitlerin de olduğu fitokimyasalların önemli bir kaynağıdır. İn vitro çalışmalar ve sınırlı sayıda in vivo hayvan çalışması ve klinik çalışmada söz konusu biyoaktif bileşiklerin, özellikle obezite, diyabet, kardiyovasküler hastalıklar ve kanser gibi çeşitli metabolik komplikasyonların oluşma riskinin azaltılmasında olumlu etki sağlayabileceği gösterilmiştir. Bu derlemede, kinoanın besin ögesi karakteristikleri, biyoaktif içeriği ve potansiyel sağllk etkileri değerlendirilmiştir. Somut bilimsel kanıtları uygulamaya daha etkin dönüştürebilmek için, kinoa ve bileşenlerinin olası sağlık etkilerini destekleyen, iyi tasarlanmış daha fazla sayıda klinik çalışmaya ihtiyaç vardır.

Anahtar kelimeler: Kinoa, fonksiyonel besin, psödo-tahillar, biyoaktif içerik, sağglk

\section{ABSTRACT}

Originating from agriculture of Andean cultures in South America, quinoa is a dicotyledonous plant that is attracting attention as a novel functional food worldwide. Although the systematical and morphological features of quinoa differ from traditional grains, Amaranthaceae family originated quinoa has been incorporated into whole grains group. Quinoa is composed of high-quality protein which is equal to the quality of casein, unsaturated fatty acids which are similar to composition of oilseeds, fiber, a variety of vitamins and highly bioavailable minerals. In addition, quinoa is a good source of phytochemicals including saponins, phytosterols, phytoecdysteroids and bioactive peptides. In vitro studies and a limited number of in vivo animal studies and clinical studies indicated that these bioactive compounds may exert beneficial effects on reducing the risk of metabolic complications such as obesity, diabetes, cardiovascular diseases and cancer. This review aims to provide an evaluation of nutritional characteristics, bioactive content and possible health effects of quinoa. There is a justified need for well-designed clinical trials demonstrating possible health effects of quinoa and its components, to determine the most effective translational applications of quinoa based on solid scientific evidence.

Keywords: Quinoa, functional food, pseudocereals, bioactive content, health

1. İletişim/Correspondence: Erciyes Üniversitesi, Sağllk Bilimleri Fakültesi, Beslenme ve Diyetetik Bölümü, Kayseri, Türkiye

E-posta: haticeozcaliskan@gmail.com • ๑ https://orcid.org/0000-0001-9351-4171
2. Hacettepe Üniversitesi, Sağlık Bilimleri Fakültesi, Beslenme ve Diyetetik Bölümü, Ankara, Türkiye

๑ https://orcid.org/0000-0001-6301-6358 


\section{GíRiş}

Günümüzde pek çok Latin Amerika ülkesinin kültürel miras olarak benimsediği ve yaklaşık 7000 yıldır yetiştirilmekte olan kinoanın (Chenopodium quinoa Willd.) tarih sahnesine çıkışı, Güney Amerika'nın And Dağları bölgesi dolaylarında hüküm sürmüş hispanik dönem öncesi uygarlıkların tarımsal faaliyetlerine dayanmaktadır (1,2). İnkalar tarafindan "anne tahıl” olarak adlandırılan ve "tanrıların armağanı" sıfatı atfedilen kinoa, İspanya’nın Güney Amerika’yı fethinden sonra sömürgeciler tarafından düşük sosyal statüyü ifade ettiği düşünülerek küçümsenmiştir. Yerel halkın dini törenlerde kinoayı kutsal içecek olarak kullandığını gören Katolik Kilisesi, kinoanın yetiştirilmemesi konusunda baskı yapmıştır $(2,3)$. Tarımının deniz seviyesinden $3500 \mathrm{~m}$ yukarıdaki Altiplano Bölgesi’nde yapılması gibi coğrafik engeller, Avrupalılar'ın kinoaya ulaşımını kısıtlamış; kinoa bazı tahıllara (buğday, çavdar, yulaf) göre daha geç tanınmıştır $(3,4)$. Ancak sınırlı bir bölgede de olsa yerel halk kinoayla ilgili tarımsal faaliyetleri sürdürmüş ve çeşitliliği de korumuştur (2).

Bolivya ve Peru, dünya genelindeki kinoa üretiminin yaklaşık \%88’ini sağlamakla birlikte Ekvador, Şili, Arjantin ve Kolombiya'da da kinoa tarımı yapılmaktadır. Bahsi geçen ülkelerde kinoanın başlıca beş farklı ekotipte yetişebilme özelliği, bitkinin çeşitliliğini arttıran önemli bir etkendir $(2,5,6)$. Mevcut durumda kinoanın yaklaşık 250 türe karşılık gelen çeşitlilikte bir genotipe sahip olması, farklı toprak türleri ve abiyotik stres faktörlerine (don, kuraklık, tuzluluk, yüksek enlem vb.) adapte olabilmesini mümkün kılmaktadır (2,7). Bitki, bağıl nemin \%4088 arasında olduğu koşullarda yetiştirilebilmekte; diğer yandan $-4^{\circ} \mathrm{C}-38^{\circ} \mathrm{C}$ sıcaklık aralığındaki iklim koşullarına uyum sağlayabilmektedir (2). Kinoa tarımı yapan ülkelerin sayısı 1980'de sekiz iken; 2010'da bu sayı 40'a ve 2014'te 75'e yükselmiş; 2015'te ise hali hazırdaki ülkelerin oluşturduğu topluluğa 20 ülke daha katılmıştır (6).

Tahıllarla ilgili en geniş kapsamlı projenin koordinatörlüğü tarafından sunulan raporda kinoa, tam tahıl tanımlamasına dahil edilmiştir (8). Kinoa, Birleşmiş Milletler Gıda ve Tarım Örgütü (Food and Agriculture Organization of the United Nations-FAO) tarafindan 21. yüzyllda sürdürülebilir beslenmeyi destekleyecek besinlerden biri olarak gösterilmiş; tarımının yapılması ve araştırılmasını teşvik etmek amaciyla 2013 yll, organizasyon tarafindan "Uluslararası Kinoa Yılı" ilan edilmiştir $(1,9)$. NASA (National Aeronautics and Space AdministrationUlusal Havacılık ve Uzay Dairesi) ise pek çok avantajını kendi çalışmalarıyla da kanıtladıkları kinoayl, uzayda görev yapan astronotların beslenme programlarına eklemiştir $(3,10)$. Bu derlemede, gıda güvencesini destekleyecek nitelikteki kinoanın besin ögesi karakteristikleri, biyoaktif içeriği, moleküler ve fizyolojik düzeydeki etkileri değerlendirilmiştir.

\section{Kinoanın Botanik Özellikleri}

Çift çenekli ve geniş yapraklı bir bitki olan kinoa, tahılların temel özelliklerini taşımasına rağmen, tek çenekli buğday, arpa, pirinç gibi geleneksel/gerçek tahılların dahil olduğu Gramineae (buğdaygiller) familyasına ait değildir. Tohumlarının olması ve öğütülebilmesi nedeniyle "psödo-tahıl” olarak ifade edilen kinoadanliteratürdebazen "psödo-yağlıtohum" olarak da bahsedilmektedir $(1,11,12)$. Amaranthaceae familyasının bir üyesi olan kinoa, sistematik ve morfolojik açıdan tahıl tanelerinden farklı özelliklere sahiptir. Söz konusu farklllıklar özellikle kinoanın tohum ve meyvelerinin anatomik yapısıyla ilgilidir (13). Kinoa meyveleri, dışarıdan perikarpla çevrelenen tek bir tohumdan oluşan sert kabuklu meyvelerdir. Merkezde karbonhidrat rezervinin olduğu perisperm bulunmakta; perispermi sırasıyla tohum ağırlığının \%60'ını oluşturan aynı zamanda protein ve lipitten zengin olan embriyo tabakası, endosperm ve tohum kabuğu kuşatmaktadır $(13,14)$.

\section{Kinoadan Elde Edilen Ürünler}

Kinoanın yaprak ve tohumları yenilebilir olmakla birlikte, bilimsel ve ekonomik yönüyle araştırmalarda 
büyük çoğunlukla kinoa tohumları konu edilmektedir (1). Kinoa tohumları, pirinç gibi pişirilerek çorba yapımında; hacim kazandırılarak kahvaltılık tahılların yapımında; un haline getirilerek ekmek, makarna, noodle, tortilla, kurabiye, bisküvi ve pankek gibi ürünlerin üretiminde kullanılabilmektedir. Tohumlarının fermente edilmesiyle bira ya da Güney Amerika'da yapılan törenlerde tercih edilen bir içecek olan "chicha” yapılmaktadır. Kinoa tohumları, patlamış mısır gibi hazırlanıp tüketilebilmekte ya da bu formda yiyeceklerin yapısına katılabilmektedir. Kinoa yapraklarının ıspanağa benzer şekilde yemekleri yapılabilmekte; kinoa filizleri salatalara eklenebilmektedir $(5,11,12,15)$. Kinoa, bazı bebek besinleri ve besin destekleri gibi ticari ürünlerin bileşiminde de bulunmaktadır (3).

\section{Kinoanın Besin Ögesi Profili ve Biyoaktif İçeriği}

Kinoa, protein kalitesi anlamında pek çok tahıla üstün gelen yönüyle alternatif bir protein kaynağı olarak sunulmaktadır (1,12). Uygun elzem aminoasit kompozisyonuyla birlikte kazein proteini ve tam yağlı süt tozunun kalitesi derecesinde yüksek kaliteli protein sağlayan birkaç bitkisel besinden biridir (1). Kuru madde üzerinden protein konsantrasyonu \%13.8-16.5 arasında değişen kinoanın protein içeriği ortalama \%15.0'tir. Söz konusu değer, arpa (\%11.0), çavdar (\%11.6), pirinç (\%8.8), sorgum (\%12.4) ve mısırın (\%10.5) protein içeriğinden yüksek olup; buğdayın protein içeriğine (\%14.8) yakındır (1). Depo proteinlerinin büyük çoğunluğunu albüminler (2S) ve globülinler (11S) oluştururken (sırasıyla \%35, \%37); prolaminler düşük konsantrasyonda bulunmakta ve oranları kinoa türleri arasında farklılık göstermektedir $(1,2)$. Gıda ve Tarım Örgütü (FAO), Dünya Sağllk Örgütü (WHO) ve Birleşmiş Milletler Üniversitesi (United Nations University-UNU) konsensusunun ilgili raporunda, insan beslenmesinde $100 \mathrm{~g}$ protein alımı için saptanan standart aminoasit profiliyle yapılan karşılaştırmaya göre, kinoanın aminoasit içeriğinin yetişkin bireylerin günlük gereksinme miktarlarını karşılayabilecek yeterlilikte (izolöysinin \%274’ü, lizinin \%338'i, triptofanın \%228'i, metionin ve sisteinin \%212'si, fenilalanin ve tirozinin \%320'si, treoninin \%331'i, histidinin \%180’i, valinin \%323’ü) olduğu vurgulanmıştır (3). Tahıllarda genellikle birinci derecede sinırlı olan lizin ve ikinci derecede sinırlı olan triptofanın yanı sıra kurubaklagillerde sinırlı olan kükürtlü aminoasitler kinoada yüksek konsantrasyonda bulunmaktadır $(1,12)$. Ayrıca $2 S$ protein fraksiyonları arjinin, histidin ve sisteinden zengin bir aminoasit kompozisyonu anlamina gelmektedir. $\mathrm{Bu}$ nedenle söz konusu protein fraksiyonları, bebek ve çocuk beslenmesinin desteklenmesinde diğer yandan besin destek ürünlerinin besin ögesi içeriklerinin zenginleştirilmesinde potansiyel önem taşımaktadır $(1,3)$. Kinoanın serbest ve proteine bağll formdaki triptofanı yüksek konsantrasyonda içermesi, ilgili aminoasidin özellikle beyinde kullanılabilirliğini arttırmaktadır (1). Prolamini düşük konsantrasyonda içeren ve gluten içeren tahıllarla filogenetik bağının uzak olması nedeniyle glutensiz tahıl olarak kabul edilen kinoanın, glutensiz ürünler tanımına (gluten içeriği <20 mg/kg) uygun olduğu gösterilmiş; çölyak hastalarınin beslenmesinde alternatif bir besin olarak yer alabileceği savunulmuştur $(2,16)$. Ancak yine de kinoanın gliadine özgü $\mathrm{T}$ hücre hatlarını ve ilgili immün yanıtları uyarma potansiyeli araştırılmaktadır (2).

Kinoanın temel karbonhidrat içeriğini, yapısında \%52-69 konsantrasyonunda bulunan nişasta oluşturmaktadır. Kinoanın toplam diyet posası içeriği, diğer tahıllarınkine benzer oranda \%7.0-9.7, çözünebilir posa içeriği ise \%1.3-6.1 arasındadır (1,12). Kinoa nişastasının amiloz içeriği, \%3-22 arasında değişirken; ilgili değer buğday ve mısırınkinden düşük, bazı arpa türlerinden yüksek ve bazı pirinç türlerinin amiloz içeriğine benzerdir. Buğday ve arpa nişastalarına kıyasla daha fazla su tutma ve şişme kapasitesine sahip olan kinoa nişastasının dondurma ve retrogradasyon aşamalarında stabilite yeteneği de yüksektir (1). Kinoanın glisemik indeks (GI) değerinin, pişirme süresine bağlı olarak 35-53 değerleri arasında değiştiği gösterilmiş; en yüksek Gİ değeri ise $150 \mathrm{~g}$ kinoanın pişirilip, dondurulup ve 
sonrasında 1.5 dakika mikrodalga firında ısıtıldıktan sonra tüketimiyle elde edilmiştir. Kinoanın posa içeriğinin etkisi de vurgulanarak, referans skalaya (0-100) göre kinoanın glisemik indeksi düşük olarak tanımlanmıştır $(2,3)$.

Kinoa, özellikle niteliksel anlamda güçlü bir lipit fraksiyonu sağladığı için alternatif yağlı tohum olarak da tanımlanabilmektedir. Kinoanın lipit içeriği ortalama \%7.0 (\%5.0-9.0) olup; misır (\%4.7) ve diğer tahılların lipit içeriğinden fazla, soya fasulyesinin lipit içeriğine (\%19.0) kıyasla düşüktür. Linoleik asit, oleik asit ve $a$-linolenik asit içerikleri değerlendirilerek karşılaştırma yapıldığında; kinoanın doymamış yağ asitleri profilinin, soya fasulyesinin söz konusu kompozisyonuyla benzerlik gösterdiği bildirilmiştir. Doymamış yağ asitleri ise kinoanın toplam yağ asidi içeriğinin yaklaşık \%88'sini oluşturmaktadır. Linoleik asit, kinoanın yağ asitleri içinde miktar olarak en büyük paya sahipken (\%49.0-56.4); onu sirasıyla oleik asit (\%19.7-29.5) ve palmitik asit (\%10.0) izlemektedir. Kinoanın a-linolenik asit konsantrasyonu da (\%8.711.7) önemli düzeydedir $(1,2,12)$. Çok sayıda hastalıkla ilişkilendirilen yüksek n-6/n-3 oranı ise kinoada ideal bir aralıkta (5.3-10.6) bulunmaktadır (14).

Kinoa; B, C ve E vitaminleri içeriği yönünden zengindir. Kinoanın özellikle a-tokoferol içeriğinin yüksek olması, yağ içeriği ve doymamışlık derecesi yüksek olan kinoanın lipit oksidasyonuna karşı korunmasında önemli bir avantaj olarak değerlendirilmektedir (1,12). Farklı tahıllarla karşılaştırıldığında, kinoanın riboflavin, pridoksin ve folat içeriğinin daha yüksek; arpa ve yulafa kıyasla tiamin konsantrasyonunun ise düşük olduğu gösterilmiştir (1,2,12). Kinoanın (100 g), yetişkinlerin günlük folik asit ve pridoksin gereksinmelerinin \%100'ünü; riboflavin gereksinmesinin \%40’ını; çocukların günlük riboflavin gereksinmesinin ise \%80’ini karşılayabildiği belirtilmiştir (12). Kinoa taneleri, geleneksel tahılların çoğuna kıyasla daha yüksek miktarda kalsiyum, magnezyum, potasyum, demir, bakır ve çinko içermektedir (Tablo 1) (12). Ayrıca kinoanın bileşimindeki kalsiyum, magnezyum ve potasyum mineralleri biyoyararlılık açısından uygun bir formda bulunurken; diğer geleneksel tahıllarla karşılaştırıldığında (1:7.8-54.0), kalsiyum:fosfor oranının (1:0.7-3.9) ideal aralıkta olduğu belirlenmiştir (2). Kinoanın demir içeriği de geleneksel tahıllara kıyasla daha yüksektir. Tanedeki saponin ve fitik asit varlığı, demirin biyoyararlılığını belirli bir dereceye kadar etkileyebilmektedir (1). Ayrıca yapılan hayvan çalışmalarında, yıkanıp parlatılmış kinoanın kullanıldığı diyet örüntüsüyle sağlanan demirin biyoyararlılığının, ferröz sülfattan sağlanan demirin biyoyararlılığı düzeyinde olduğu gösterilmiştir. Diğer taraftan kinoanın bileşimindeki minerallerin insanlarda da biyoyararlılık düzeylerinin çalışılması, araştırılmayı bekleyen bir konudur $(1,17)$.

Fitoekdisteroidler, fitosteroller, saponinler, skualen, peptitler, betalainler, izoflavonlar, flavonol glikozitleri, lektinler, polisakkaritler, karotenoidler ve fagopritoller, kinoanın yapısındaki başlıca biyoaktif bileşikler olarak tanımlanmıştır (2,12,14,15). Kinoanın özellikle biyoaktif bileşiklerle ilgili kompozisyonu ve söz konusu bileşiklerin etkileri çevresel stres faktörlerine göre farklılaşmaktadır. Örneğin, tuz oranının yüksek olduğu bir çevrede yetiştirilen kinoanın fenolik içeriğinin ve antioksidan kapasitesinin arttığı; soğuk ve yağmurlu bir bölgede yetiştirilen kinoaya kıyasla sıcak ve kurak bir ortamda yetiştirilen kinoanın ise fenolik içeriği ve proksimat analizi bileşenlerinin (protein hariç) arttığı gösterilmiştir (2).

\section{Kinoadaki Besin Ögesi Olmayan Faktörler}

Kinoanın özellikle dış tabakasında bulunan fitatlar, taninler, saponinler, nitratlar, okzalatlar ve tripsin inhibitörleri, besin ögesi olmayan faktörler olarak tanımlansa da bu bileşiklerin etkilerine yönelik çalışmalar sınırlıdır. Ayrıca çeşitli endüstriyel işlemler ve evde uygulanan geleneksel yöntemlerle söz konusu faktörler inaktive edilebilmekte ya da sağlık açısından güvenilir düzeylere indirgenebilmektedir. Diğer yandan kinoadaki ilgili bileşikler, diğer tahıllar ya da kuru baklagillerdeki eşdeğerlerine kıyasla daha düşük ya da benzer miktardadır (1). Örneğin kinoanın saponin içeriği, soya fasulyesi ya da diğer 
Tablo 1. Kinoa, Buğday ve Pirincin Enerji ve Besin Ögesi İçeriği (14)

\begin{tabular}{|c|c|c|c|}
\hline Enerji ve Besin Ögeleri & Kinoa & Buğday & Pirinç \\
\hline Enerji (kkal) & $357-368$ & 340 & 354 \\
\hline Toplam protein ${ }^{\mathrm{a}}$ & $13.1-16.7$ & 11.3 & 6.8 \\
\hline Toplam yağa & $5.5-7.4$ & 1.7 & 0.7 \\
\hline Karbonhidrat $^{\mathrm{a}}$ & $59.9-74.7$ & 63.7 & 79.7 \\
\hline Posa $^{\mathrm{a}}$ & $7.0-11.7$ & 12.2 & 0.6 \\
\hline $\mathrm{Kül}^{\mathrm{a}}$ & $2.7-3.8$ & 1.5 & 0.5 \\
\hline \multicolumn{4}{|l|}{ Mineraller ${ }^{\mathrm{b}}$} \\
\hline Kalsiyum & $27.5-148.7$ & 35.0 & 22.0 \\
\hline Demir & $1.4-16.7$ & 5.0 & 1.4 \\
\hline Magnezyum & $26.0-502.0$ & 103.0 & NA \\
\hline Fosfor & $140.0-530.0$ & 393.0 & 119.0 \\
\hline Potasyum & $696.7-1475.0$ & 478.0 & 80.0 \\
\hline Sodyum & $11.0-31.0$ & 2.0 & 31.0 \\
\hline Çinko & $2.8-4.8$ & 3.7 & 0.6 \\
\hline Bakır & $1.0-9.5$ & 0.4 & 0.1 \\
\hline \multicolumn{4}{|l|}{ Vitaminler $^{\mathrm{b}}$} \\
\hline Askorbik asit (C) & $4.0-16.4$ & ND & ND \\
\hline a-tokoferol (E) & $2.6-5.4$ & 1.4 & 0.7 \\
\hline Tiamin $\left(\mathrm{B}_{1}\right)$ & $0.3-0.4$ & 0.5 & 0.2 \\
\hline Riboflavin $\left(\mathrm{B}_{2}\right)$ & $0.3-0.4$ & 0.1 & 0.1 \\
\hline Niasin $\left(B_{3}\right)$ & $1.1-1.5$ & 5.1 & 4.4 \\
\hline Pridoksin $\left(\mathrm{B}_{6}\right)$ & 0.5 & 0.3 & 0.3 \\
\hline Folat & 0.2 & 0.1 & 0.1 \\
\hline \multicolumn{4}{|l|}{ Elzem Aminoasitler ${ }^{\mathrm{c}}$} \\
\hline Histidin & $1.4-5.4$ & 2.4 & 2.4 \\
\hline İzolöysin & $0.8-7.4$ & 4.3 & 4.3 \\
\hline Löysin & $2.3-9.4$ & 8.3 & 8.3 \\
\hline Lizin & $2.4-7.8$ & 3.6 & 3.6 \\
\hline Metionin & $0.3-9.1$ & 2.4 & 2.4 \\
\hline Sistein & $0.1-2.7$ & 2.1 & 2.0 \\
\hline Fenilalanin + Tirozin & $2.7-10.3$ & 8.7 & 8.7 \\
\hline Treonin & $2.1-8.9$ & 3.6 & 3.6 \\
\hline Triptofan & $0.6-1.9$ & 1.2 & 1.2 \\
\hline Valin & $0.8-6.1$ & 6.1 & 6.1 \\
\hline
\end{tabular}

${ }^{a} \mathrm{~g} / 100 \mathrm{~g}$

${ }^{b} \mathrm{mg} / 100 \mathrm{~g}$

c $g / 100$ g protein

NA: not available (analiz verisi yoktur); ND: not detected (analizde tespit edilmemiştir)

kuru baklagillerin saponin içeriğine kıyasla çok daha düşüktür. Karakteristik acı tada sahip saponinin miktarı ise duyusal kalite ve tüketici memnuniyetinin arttırılması amacıyla genellikle azaltılmaktadır. Bunun için geliştirilen yöntemler ise hem saponin içeriğini etkin düzeyde azaltmakta hem de besin ögesi içeriğini korumaktadır $(1,3,14)$. Kinoanın beş farklı türü için belirlenen fitik asit konsantrasyonunun da arpa, mısır, buğday ve pirincin fitik asit içeriğine yakın olduğu gösterilmiştir (18). Ayrıca fitatların 
olası negatif etkilerine rağmen; izole formlarının antikarsinojenik ve antioksidan etkileri olduğu kanıtlanmıştır $(3,14)$.

\section{Kinoanın Potansiyel Sağlık Etkileri - Preklinik Çalışmalar}

Yirmi birinci yüzyılın önde gelen tahılları arasında gösterilen kinoa, zengin biyoaktif içeriği ve nitelikli besin ögesi kompozisyonuyla sağlayacağı potansiyel sağlık etkileri nedeniyle araştırmacıları çalışmaya yöneltmiştir. Çeşitli teröpatik özelliklerinin vurgulandığı güncel araştırmalarla birlikte fonksiyonel besin olarak tanınmaya başlanan kinoanın özellikle biyoaktif içeriği, söz konusu etkilerde sorumlu tutulmaktadır (2,12,14,15). Yukarıda bahsedilen biyoaktif bileşiklerin çoğunlukla in vitro çalışmada; sınırlı sayıda da in vivo hayvan çalışmasında antioksidan, antiinflamatuvar, antiaterosklerotik, antidiyabetik, hipokolesterolemik, antiobezite, antikarsinojenik, antimikrobiyal, antialerjik, nöroprotektif, immünomodülatör, gastroprotektif etkileri ve anjiyotensin dönüştürücü enzimin inhibisyonu gibi etkileri belirlenmiştir $(1,2,12-15,19-21)$.

Bazı tahılların ve psödo-tahılların toplam antioksidan potansiyellerinin dört farklı yöntemle karşılaştırıldığg bir araştırmada, tüm yöntemlerde sağlanan verilerde psödo-tahılların antioksidan potansiyellerinin, pirinç vekarabuğdaygibitahıllarakıyasladahayüksekolduğu gösterilmiştir (22). Kinoa tohumlarından ekstrakte edilen polisakkaritlerin ve bazı alt fraksiyonlarının da olası antioksidan etkileri belirlenmiş ve söz konusu polisakkaritlerin güçlü immünoregülatör etkinliği vurgulanmıştır (20). Oksidatif stres oluşturulan ratlarda kinoa içeren diyetin, plazmadaki ve bazı organlardaki oksidatif sürece etkilerini inceleyen bir çalışmada diyetin kinoayla desteklenmesi, plazma malondialdehit düzeyinde, antioksidan enzim aktivitesinde ve lipit peroksidasyonunda azalmayla sonuçlanmış; kinoanın plazma, kalp, pankreas, böbrekler, testisler ve akciğerlerin antioksidan kapasitesini arttırabileceği kanıtlanmıştır (23). Mürin makrofaj hücrelerinde, kinoadan ekstrakte edilen saponin fraksiyonlarının antiinflamatuvar aktivitesi değerlendirilmiştir. Bazı saponin fraksiyonlarının, inflamasyonun çoğu aşamasında etkin rol oynayan nitrik oksidin üretimini doz-yanıt ilişkisi çerçevesinde azalttığı; tümör nekrozis faktör- $\alpha$ ve interlökin-6 gibi inflamatuvar sitokinlerin salınımını ise inhibe ettiği gösterilmiştir (21). Diğer bir in vitro çalışmada, kinoanın yapısındaki bazı fenolik bileşiklerin a-amilaz ve a-glikosidaz enzimlerinin aktivasyonunu inhibe edebileceği gösterilmiş; bu bağlamda söz konusu biyoaktif bileşiklerin intestinal glikoz emilimi ve dolayısıyla postprandiyal gliseminin kontrolünde önemli rol üstlenebilecekleri ifade edilmiştir (19).

Kinoa, insan beslenmesinde en yüksek fitoekdisteroid (polihidroksillenmiş steroidler) içeriğine sahip tarımsal ürün olup; 138-570 $\mu \mathrm{g} / \mathrm{g}$ konsantrasyonunda ekdisteroid içermektedir. Kinoa fitoekdisteroidlerinin \%62-90'ını ise 20-hidroksiekdizon (20HE) oluşturmaktadır (2,12,15). 20HE’nin memeli metabolizmasındaki fizyolojik etkilerine ilişkin veriler sinırlı olsa da in vitro ve in vivo çalışmalarda özellikle adipozite, glikoz metabolizması ve enerji homeostazında önemli etkiler sağlayabileceği gösterilmiştir (24-26). Yüksek yağlı diyetle obezite ve hipergliseminin tetiklendiği C57BL/6J ratlarda, 13 hafta süresince 20HE (10 mg/kg) desteği, adipozitede azalma ve insülin direncinde iyileşmeyle sonuçlanmış; bu duruma viseral yağ dokusu kaynaklı üretilen adiponektin konsantrasyonunda yaşanan artış ile hepatik fosfoenol pirüvat karboksikinaz ve glikoz-6-fosfataz enzimlerinin ekspresyonunda görülen azalma eşlik etmiştir (26). Yüksek yağll diyetle beslenen farelerde, üç hafta süresince 20HE ile zenginleştirilmiş kinoa ekstraktının (Q) uygulanması ya da tek başına 20HE suplemantasyonu, enerji harcaması, glikoz oksidasyonu ve fekal yolla lipit atımını arttırarak enerji homeostazını desteklemiştir (24).Aynıçalışma modelinin diğer bulgularında, adipoz dokudaki gelişimsel değişiklikler ve adipozitlere özgü gen ekspresyonu değerlendirilmiştir. Yüksek yağlı diyetle beslenen grupta, tek başına $20 \mathrm{HE}$ ya da Q suplemantasyonunun, vücut ağırlığını etkilemeden adipoz doku gelişimini azalttığı belirlenmiştir. 
Adipoz dokuya ilişkin bu etki, adipozit büyüklüğünde ve lipit depolanmasında görevli bazı genlerin ekspresyonundaki azalmayla ilişkilendirilmiştir. Q desteği sağlanan farelerde, yüksek yağlı diyetle beyaz adipoz dokuda transkripsiyonu tetiklenen çeşitli inflamasyon ve insülin direnci belirteçlerinin (interlökin-1 $\beta$, toll benzeri reseptör-4, monosit kemotaktik protein-1, CD68, plazminojen aktivatör inhibitörü) mRNA düzeylerinde de azalma sağlanmıştır (25). Ayrıca in vitro bir çalışmada, iskelet kası hücrelerinde 20HE uygulamasının anabolik PI3K/AKT sinyalizasyon yolağının aktivasyonunu destekleyecek şekilde gen ekspresyonunu etkilediği ve protein sentezini arttırdığı; diğer bir çalışmada ise C57BL/6J farelerde subkutan yolla sağlanan 20HE’nin bazı kas dokularında artışı tetiklediği gösterilmiştir $(27,28)$.

Erkek Wistar ratların deneysel diyet örüntülerinde protein kaynağı olarak (miktar olarak tüm diyetin \%20'si) kazein (kontrol grubu), kinoa ya da amarantın 15 gün süresince kullanıldığı bir çalışmada, kinoa grubunda postprandiyal glikoz ve plazma trigliserit düzeylerindeki azalma anlamlı oranda saptanmazken ( $p>0.01$ ); kontrol grubuyla karşılaştırıldığında total kolesterol (TC) düzeyindeki azalma miktarının kinoa ve amarant gruplarında anlamlı olduğu (her iki grup için $\mathrm{p}$ <0.01) gösterilmiştir (29). Erkek Wistar ratlarda, diyet örüntüsüne \%31 oranında fruktozun eklendiği bir çalışma modelinde, bahsedilen diyetin kinoayla desteklenmesinin çeşitli biyokimyasal parametrelere dair etkileri değerlendirilmiştir. Fruktozun kontrol diyetine eklenmesiyle plazma yüksek yoğunluklu lipoprotein kolesterol (HDL-C) düzeyinde gözlenen anlamlı derecedeki azalma $(\mathrm{p}<0.05)$, söz konusu diyetin kinoayla desteklenmesiyle engellenmiştir. Kontrol grubuna kiyasla, kinoa grubunda plazma düşük yoğunluklu lipoprotein kolesterol (LDL-C) konsantrasyonunda $(\% 57, \quad \mathrm{p}<0.008), \quad$ TC konsantrasyonunda $(\% 26, \quad \mathrm{p}<0.05)$ ve trigliserit düzeyinde $(11 \%, p<0.05)$ etkin derecede azalma sağlanmıştır. Ayrıca kinoa grubunda, serum glikoz düzeyindeki azalma oranının da anlamlı olduğu (\%10, p<0.01) gösterilmiştir (30). Erkek obez diyabetik $(\mathrm{db} / \mathrm{db})$ farelerde sekiz hafta sürdürülen deneysel bir çalışmada, kırmızı kinoanın eklendiği kontrol diyeti alan grupta, kontrol grubuna kıyasla, hepatik steatoz, plazma lipit profili ve inflamatuvar-oksidatif stres tablosunun anlamlı derecede iyi olduğu gösterilmiştir (31).

\section{Kinoanın Potansiyel Sağlık Etkileri - Klinik Çalışmalar}

Kinoa tüketiminin insan sağlığına ilişkin olası etkilerini araştıran klinik çalışmalar oldukça sınırlıdır. Ekvador-Quito'da, aileleri düşük gelir düzeyine sahip, kreşe giden, beslenme yetersizliği olan, yaşları 50-65 ay arasında değişen 40 erkek çocuğun dahil edildiği bir çalışmada, 15 gün boyunca her gün kinoa unundan yapılan lapa veya içecek tüketiminin, plazma insülin benzeri büyüme faktörü-1 düzeyinde anlamlı düzeyde artışa neden olduğu belirlenmiştir $(\mathrm{p}<0.05)$. Kinoa ile hazırlanan besinler, bu yaş grubundaki çocukların günlük enerji gereksinmesinin \%40'ını; protein için günlük önerilen güvenilir alım düzeyinin ise \%30'unu karşılayacak miktarda sağlanmış ve iki öğünde sunulmuştur (32).

Yirmi iki öğrenciden (18-45 yaş) oluşan bir çalışma grubunda, otuz gün boyunca kinoanın tahıl barı formunda günlük tüketimi (19.5 g kinoa/ gün) sonucunda, plazma LDL-C, TC ve trigliserit konsantrasyonlarında anlamlı düzeyde azalma sağlanırken (ilk ikisi için $\mathrm{p}<0.001$, trigliserit için $\mathrm{p}<0.05$ ); kan glikoz düzeyi, kan basıncı ve vücut ağırlığı değişkenlerinde ise değişiklik saptanmamıştır (33). Postmenopozal dönemdeki 35 hafif şişman kadında, kinoa gevreği ya da mısır gevreğinin dört hafta süresince (25 g/gün) sağlandığı prospektif çift kör bir çalışmada, serum trigliserit, tiyobarbitürik asit reaktif ürünleri ve $\mathrm{E}$ vitamini düzeyleri, her iki çalışma grubunda da anlamlı derecede azalmıştır. Ancak serum LDL-C ve TC düzeylerindeki azalma ile indirgenmiş glutatyon düzeyindeki artış yalnızca kinoa grubunda anlamlı (her biri için $\mathrm{p}<0.05$ ) bulunmuştur (34). Randomize çift kör çapraz bir çalışmada, 50-75 yaş arasındaki sağlıklı 40 katılımcıda, 28 gün süresince standart diyetle birlikte günde iki 
kez 15 g kinoalı bisküvi (60 g kinoa unu/100 g ürün karışımı) tüketimiyle sağlanan vücut ağırlığı kaybı ve lipit profilindeki iyileşmenin anlamlı olduğu bildirilmiştir (35).

Yetişkin 19 çölyak hastasının [medyan yaş=59 yll, medyan BKİ (beden kütle indeksi) $=23 \mathrm{~kg} / \mathrm{m}^{2}$, medyan glutensiz diyet uygulama süresi=9 yıl], glutensiz diyet programını sürdürerek altı hafta süresince günlük 50 g kinoa tükettikleri bir araştırmada, serolojik ve gastrointestinal semptomlar değerlendirilmiştir. Kinoanın kahvaltıda lapa ya da pankek formunda; pirinç gibi pişirilip tek başına ya da garnitür formunda tüketilmesi önerilmiş; salatalara da eklenebileceği bildirilmiştir. Ayrıca hastalara yemeklerin içinde tüketilebileceği de anlatılmıştır. Kinoanın glutensiz diyete eklenmesi, çölyak hastalarında tolere edilmiş; hatta çalışma sonunda hastaların gastrointestinal bulgularında iyileşme sağlanmıştır. Çalışma başlangıcında villus yüksekliğinin kript derinliğine oranı 2.8:1 iken; çalışma sonunda bu oran 3:1'e çıkmış (normal aralık = 5:1- 3:1); yüzey enterosit hücre yüksekliği $28.76 \mu$ m'den $29.77 \mu$ m'e yükselmiş (normal aralık = 29- $34 \mathrm{~nm}$ ); her 100 enterosit için intraepitelyal lenfosit sayısı 30.3'ten 29.7'ye düşmüştür (<20'den düşük olması normal kabul edilmektedir) (16).

\section{SONUÇ VE ÖNERİLER}

Kinoa, biyoaktif bileşiklerin kaynağı olup, aynı zamanda nitelikli bir besin ögesi kompozisyonuna sahiptir. Bir porsiyon kinoanın (yaklaşık $40 \mathrm{~g}$ ), besin ögelerinin günlük alınması önerilen miktarlarının önemli bir kısmını karşılayacak yeterlilikte olduğu bildirilmiştir. $\mathrm{Bu}$ bağlamda kinoa, sürdürülebilir beslenmenin desteklenmesinde 21. yüzyılın lokomotif besinleri arasında gösterilmektedir. Yapılan in vitro çalışmalarda, sınırlı sayıdaki in vivo hayvan çalışması ve klinik çalışmada da kinoanın metabolik risk faktörlerinin kontrolünde dolayısıyla obezite, tip 2 diyabet, kardiyovasküler hastalıklar ve kanserin önlenmesi ya da söz konusu hastalıklardan kaynaklanan metabolik defektlerin iyileştirilmesinde etkin rol oynayabileceği gösterilmiştir. Kinoanın özellikle biyoaktif bileşikleri ve miktarlarının tanımlanmasına; etki mekanizmaları ve biyoyararlılıklarının aydınlatılmasına yönelik araştırmalara ihtiyaç vardır. Ayrıca kinoanın moleküler ve fizyolojik düzeydeki etkileri, hayvan çalışmaları ve iyi tasarlanmış klinik çalışmalarla desteklenmelidir. Toplumda kinoanın fonksiyonel etkilerine ilişkin farkındalığın oluşturulması, yeterli ve dengeli bir beslenme örüntüsüne dahil edilmesi ve tüketiciye ulaştırılabilmesine ilişkin olarak bütünleyici stratejiler geliştirilmelidir.

Çıkar çatışması - Conflict of interest: Yazarlar çıkar çatışması olmadığın beyan ederler. - The authors declare that they have no conflict of interest.

\section{KAYNAKLAR}

1. Filho AM, Pirozi MR, Borges JT, Pinheiro Sant'Ana HM, Chaves JB, Coimbra JS. Quinoa: Nutritional, functional, and antinutritional aspects. Crit Rev Food Sci Nutr. 2017;57(8):1618-30.

2. Lutz M, Bascuñán-Godoy L. The Revival of Quinoa: A Crop for Health. Waisundara V, Shiomi N, editors. Superfood and Functional Food - An Overview of Their Processing and Utilization. Croatia: InTech; 2017.

3. Bastidas EG, Roura R, Rizzolo DAD, Massanés T, Gomis R. Quinoa (Chenopodium quinoa Willd), from nutritional value to potential health benefits: An integrative review. J Nutr Food Sci. 2016;06(03):1-10.

4. Vega-Galvez A, Miranda M, Vergara J, Uribe E, Puente L, Martinez EA. Nutrition facts and functional potential of quinoa (Chenopodium quinoa willd.), an ancient Andean grain: A review. J Sci Food Agric. 2010;90(15):2541-7.

5. Sharma V, Chandra S, Dwivedi P, Parturkar M. Quinoa (Chenopodium quinoa Willd.): A nutritional healthy grain. Int J Adv Res. 2015;3(9):725-736.

6. Bazile D, Jacobsen SE, Verniau A. The global expansion of quinoa: Trends and limits. Front Plant Sci. 2016;7:622.

7. Navruz-Varli S, Sanlier N. Nutritional and health benefits of quinoa (Chenopodium quinoa Willd.). J Cereal Sci. 2016;69:371-6.

8. Van der Kamp JW, Poutanen K, Seal CJ, Richardson DP. The HEALTHGRAIN definition of 'whole grain'. Food Nutr Res. 2014;58:1-8.

9. Bazile D, Bertero D, Nieto C. State of the Art Report of Quinoa in the World in 2013. Rome: Food and Agriculture Organization of the United Nations; 2015. 
10. Schlick G, Bubenheim L. Quinoa: An emerging new crop with potential for Controlled Ecological Life Support System. Report/Patent Number: NASA-TP-3422, A-93100, NAS 1.60:3422.

11. Valcárcel-Yamani B, Silva Lannes SC. Applications of quinoa (Chenopodium Quinoa Willd.) and amaranth (Amaranthus Spp.) and their influence in the nutritional value of cereal based foods. Food and Public Health. 2012;2(6): 265-275.

12. Vilcacundo R, Hernández-Ledesma B. Nutritional and biological value of quinoa ( Chenopodium quinoa Willd.). Curr Opin Food Sci. 2017;14:1-6.

13. Graf BL, Poulev A, Kuhn P, Grace MH, Lila MA, Raskin I. Quinoa seeds leach phytoecdysteroids and other compounds with anti-diabetic properties. Food Chem. 2014;163:178-85.

14. Tang Y, Tsao R. Phytochemicals in quinoa and amaranth grains and their antioxidant, anti-inflammatory, and potential health beneficial effects: A review. Mol Nutr Food Res. 2017;61(7):1-16.

15. Graf BL, Rojas-Silva P, Rojo LE, Delatorre-Herrera J, Baldeón ME, Raskin I. Innovations in health value and functional food development of quinoa (Chenopodium quinoaWilld.). Compr Rev Food Sci Food Saf. 2015;14(4):431-45.

16. Zevallos VF, Herencia LI, Chang F, Donnelly S, Ellis HJ, Ciclitira PJ. Gastrointestinal effects of eating quinoa (Chenopodium quinoa Willd.) in celiac patients. Am J Gastroenterol. 2014;109(2):270-8.

17. Nowak V, Du J, Charrondiere UR. Assessment of the nutritional composition of quinoa (Chenopodium quinoa Willd.). Food Chem. 2016;193:47-54.

18. Kozioł MJ. Chemical composition and nutritional evaluation of quinoa (Chenopodium quinoa Willd.). J Food Compost Anal.1992;5(1):35-68.

19. Tang Y, Zhang B, Li X, Chen PX, Zhang H, Liu R, et al. Bound phenolics of quinoa seeds released by acid, alkaline, and enzymatic treatments and their antioxidant and alphaglucosidase and pancreatic lipase inhibitory effects. J Agric Food Chem. 2016;64(8):1712-9.

20. Yao Y, Shi Z, Ren G. Antioxidant and immunoregulatory activity of polysaccharides from quinoa (Chenopodium quinoa Willd.). Int J Mol Sci. 2014;15(10):19307-18.

21. Yao Y, Yang X, Shi Z, Ren G. Anti-inflammatory activity of saponins from quinoa (Chenopodium quinoa Willd.) seeds in lipopolysaccharide-stimulated RAW 264.7 macrophages cells. J Food Sci. 2014;79(5):H1018-23.

22. Gorinstein S, Lojek A, Milan Č, Pawelzik E, Delgado-Licon E, Medina OJ, et al. Comparison of composition and antioxidant capacity of some cereals and pseudocereals. Int J Food Sci. 2008;43(4):629-37.

23. Pasko P, Barton H, Zagrodzki P, Izewska A, Krosniak
M, Gawlik M, et al. Effect of diet supplemented with quinoa seeds on oxidative status in plasma and selected tissues of high fructose-fed rats. Plant Foods Hum Nutr. 2010;65(2):146-51.

24. Foucault AS, Even P, Lafont R, Dioh W, Veillet S, Tome $\mathrm{D}$, et al. Quinoa extract enriched in 20-hydroxyecdysone affects energy homeostasis and intestinal fat absorption in mice fed a high-fat diet. Physiol Behav. 2014;128:22631.

25. Foucault AS, Mathe V, Lafont R, Even P, Dioh W, Veillet $\mathrm{S}$, et al. Quinoa extract enriched in 20-hydroxyecdysone protects mice from diet-induced obesity and modulates adipokines expression. Obesity (Silver Spring). 2012;20(2):270-7.

26. Kizelsztein P, Govorko D, Komarnytsky S, Evans A, Wang Z, Cefalu WT, et al. 20-Hydroxyecdysone decreases weight and hyperglycemia in a diet-induced obesity mice model. Am J Physiol Endocrinol Metab. 2008;296(3):E433-E9.

27. Cheng DM, Kutzler LW, Boler DD, Drnevich J, Killefer J, Lila MA. Continuous infusion of 20-hydroxyecdysone increased mass of triceps brachii in C57BL/6 mice. Phytother Res. 2013;27(1):107-11.

28. Gorelick-Feldman J, Cohick W, Raskin I. Ecdysteroids elicit a rapid $\mathrm{Ca} 2+$ flux leading to Akt activation and increased protein synthesis in skeletal muscle cells. Steroids. 2010;75(10):632-7.

29. Mithila MV, Khanum F. Effectual comparison of quinoa and amaranth supplemented diets in controlling appetite; a biochemical study in rats. J Food Sci Technol. 2015;52(10):6735-41.

30. Pasko P, Zagrodzki P, Barton H, Chlopicka J, Gorinstein S. Effect of quinoa seeds (Chenopodium quinoa) in diet on some biochemical parameters and essential elements in blood of high fructose-fed rats. Plant Foods Hum Nutr. 2010;65(4):333-8.

31. Noratto GD, Murphy K, Chew BP. Quinoa intake reduces plasma and liver cholesterol, lessens obesity-associated inflammation, and helps to prevent hepatic steatosis in obese db/db mouse. Food Chem. 2019;287:107-14.

32. Ruales J, Grijalva Yd, Lopez-Jaramillo P, Nair BM. The nutritional quality of an infant food from quinoa and its effect on the plasma level of insulin-like growth factor-1 (IGF-1) in undernourished children. Int J Food Sci Nutr. 2009;53(2):143-54.

33. Farinazzi-Machado FMV, Barbalho SM, Oshiiwa M, Goulart R, Pessan Junior O. Use of cereal bars with quinoa (Chenopodium quinoa W.) to reduce risk factors related to cardiovascular diseases. Food Sci Technol (Campinas). 2012;32(2):239-44.

34. De Carvalho FG, Ovídio PP, Padovan GJ, Jordão Junior AA, Marchini JS, Navarro AM. Metabolic parameters of postmenopausal women after quinoa or corn flakes 
intake - a prospective and double-blind study. Int J Food Sci Nutr. 2013;65(3):380-5.

35. Pourshahidi LK, Caballero E, Osses A, Hyland BW, Ternan NG, Gill CIR. Modest improvement in CVD risk markers in older adults following quinoa (Chenopodium quinoa Willd.) consumption: a randomized-controlled crossover study with a novel food product. Eur J Nutr. 2020;10.1007/s00394-019-02169-0. 